\title{
UPAYA MENINGKATKAN MOTIVASI BELAJAR SISWA DENGAN METODE BIMBINGAN KELOMPOK DI SMAN 9 KOTA JAMBI
}

\author{
ARMINI \\ SMA Negeri 9 Kota Jambi Provinsi Jambi \\ Email : armini.240866@gmail.com
}

\begin{abstract}
ABSTRAK
Penelitian ini bertujuan untuk mengetahui keefektifan penggunaan Bimbingan Kelompok untuk meningkatkan motivasi belajar siswa kelas X MIPS 2 di SMA Negeri 9 Kota Jambi Provinsi Jambi. Metode penelitian yang digunakan adalah Penelitian Tindakan Kelas (PTK) Bimbingan Konseling yang terdiri atas 2 siklus. Subyek penelitian adalah siswa kelas X MIPS 2 di SMA Negeri 9 Kota Jambi tahun ajaran 2019/2020 sebanyak 35 siswa. Analisis data menggunakan teknik analisis diskriptif komparatif dengan membandingkan kondisi awal dengan hasil-hasil yang dicapai pada setiap siklus, dan analisis deskriptif kualitatif hasil observasi dengan membandingkan hasil observasi dan refleksi pada siklus I dan siklus II. Berdasarkan hasil analisis data pelaksanaan tindakan pada siklus I menunjukkan bahwa prosentase motivasi belajar sedang sebanyak $20 \%$, rendah sebesar $40 \%$ dan motivasi belajar kategori sangat rendah $40 \%$. Sedangkan berdasarkan hasil analisis siklus II diperoleh siswa memiliki motivasi belajar sangat tinggi sebanyak 10\%, tinggi sebesar 50\% dan motivasi belajar kategori sedang sebesar $10 \%$ dan rendah $10 \%$, sehingga berdasarkan hasil siklus II tersebut telah mencapai indikator keberhasilan penelitian yang telah ditetapkan. Dengan demikian subjek yang dijadikan penelitian yang berjumlah 30 orang siswa kelas X MIPS 2 di SMA Negeri 9 Kota Jambi dapat meningkatkan motivasi siswa dalam belajar.
\end{abstract}

Kata Kunci: motivasi belajar, bimbingan kelompok

\section{PENDAHULUAN}

Pendidikan nasional berfungsi mengembangkan kemampuan dan membentuk watak serta peradaban bangsa yang bermartabat dalam rangka mencerdaskan kehidupan bangsa, bertujuan untuk berkembangnya potensi siswa agar menjadi manusia yang beriman dan bertaqwa kepada Tuhan yang maha esa, berakhlak mulia, sehat, berilmu, cakap, kreatif,mandiri dan menjadi warga negara yang demokratis serta bertanggung jawab. Berdasarkan batasan di atas, maka pendidikan Indonesia ini tidak hanya memprioritaskan perkembangan aspek kognitif atau pengetahuan siswa, namun juga perkembangan individu sebagai pribadi yang unik secara utuh. Oleh karena itu setiap satuan pendidikan harus memberikan layanan yang dapat memfasilitasi perkembangan pribadi siswa secara optimal berupa bimbingan dan konseling.

Siswa di SMA mempunyai tingkat perkembangan kepribadian sosial yang berada pada masa transisi dari anak-anak ke remaja. Masa remaja di sekolah menengah menghadapi beberapa aspek utama perkembangan kejiwaan anak. Remaja pada masa peralihan tersebut bisa saja mengalami penyimpangan prilaku bila berada dalam lingkungan yang tidak kondusif (Musnadi, 2017). Latar belakang sosial budaya yang berbeda, faktor ekonomi yang rendah, faktor keluarga yang kurang mendukung kesemuanya itu akan berpengaruh pada motivasi belajar anak di sekolah. Dengan kondisi perkembangan remaja pada masa ini, maka proses pendidikan memerlukan kondisi yang mendukung dan kondusif agar perkembangan kemampuan kognitif, efektif dan psikomotorik remaja dapat mencapai tujuan yang diharapkan. Menurut Akbar Ridho (2012): “Ada beberapa aspek lingkungan yang mempengaruhi prestasi belajar siswa. Aspek-aspek ini diantaranya adalah lingkungan sekolah, lingkungan keluarga, lingkungan masyarakat,". Apa yang dilakukan guru baik di rumah, di sekolah dan masyarakat harus sesuai dengan ketentuan pendidikan, demikian pula hanya ketidakbaikan, semuanya memberikan persepsi dan perlakuan yang sama. Tetapi dalam kenyataannya tidaklah selalu demikian betapa banyak kontradiksi dan pertentangan antara yang satu dengan yang lainnya. Di rumah sesuatu yang diyakini sebagai hal yang banyak dan tidak boleh dilakukan, tetapi hal 


\section{EDUCATOR : Jurnal Inovasi Tenaga Pendidik dan Kependidikan Vol. 1 No. 1 September 2021, e-ISSN : 2807-8659 | p-ISSN : 2807-8829}

tersebut dengan leluasa di masyarakat dapat disaksikan oleh remaja yang dilakukan orangorang. Lingkungan sangat berperan dalam menciptakan gairah (motivasi) siswa dan secara sosial sangat berpengaruh terhadap proses pembelajaran (Damanik, 2019). Maka peran guru dalam membimbing siswa dalam memahami setiap pengetahuan yang didapatkan baik dengan cara, dilihat, didengar dan dirasakan dari lingkungan haruslah benar-benar hadir dalam setiap kebimbangan siswa. Guna mengatasi permasalahan tersebut maka Bimbingan Konseling (selanjutnya dibaca BK) menjadi salah satu pilihan solusi dalam mengentaskan permasalahan motivasi belajar siswa yang kurang.

Bimbingan konseling merupakan salah satu mata pelajaran yang dikhususkan untuk membina dan membimbing siswa-siswi yang mempunyai masalah baik itu masalah internal maupun external yang mana Bimbingan Konseling (BK) mencakup hal-hal yang berkenaan dengan pribadi, kemasyarakatan, belajar, dan karier siswa (Hanan, 2017). Bimbingan kelompok merupakan salah satu jenis layanan Bimbingan yang diselenggarakan di sekolah. Menurut Prayitno \& Ermananti (2005: 47) mengemukakan bahwa bimbingan kelompok adalah suatu kegiatan yang dilakukan secara kelompok yang memanfaatkan dinamika kelompok. Artinya semua anggota kelompok dalam kegiatan kelompok saling berinteraksi, bebas mengelaurkan pendapat, menanggapi dan memberi saran dan lain-lain, apa yang dibicarakan itu semuanya bermanfat untuk peserta yang bersangkutan sendiri dan untuk peserta lainnya (Khairani, 2019).

Dalam kegiatan pembelajaran akan didapati kegiatan interaksi atau komunikasi yang berlangsung antara guru dan siswa. Komunikasi tersebut menjadi kegiatan dalam mentransfer ilmu dan pengetahuan dalam kegiatan tersebut sebagai bagian dari interaksi guru dan siswa. Untuk dapat memahami interaksi itulah secara khusus dikenal istilah interaksi belajar mengajar yang titik penekanannya ada pada motivasi (Fitriati, 2017). Motivasi inilah yang mendorong seseorang untuk melakukan sebuah pekerjaan maupun kegiatan seperti halnya belajar. Hasil belajar akan menjadi optimal jika ada motivasi belajar. Dengan motivasi, pelajar dapat mengembangkan aktivitas dan inisiatif kearah yang lebih baik. Jadi motivasi merupakan salah satu faktor yang sangat penting dalam kehidupan manusia, demikian pentingnya sampai ada pernyataan bahwa motivasi adalah energi yang dimiliki seseorang untuk belajar (Sardiman,2010:73).

Motivasi mendorong dan mengarah pada minat belajar untuk tercapai suatu tujuan. Siswa akan bersungguh-sungguh belajar karena termotivasi mencari prestasi, mendapat kedudukan dalam sebuah posisi, menjadi tokoh dan mampu memecahkan masalah. Jadi seorang termotivasi untuk mendapatkan sesuatu, maka ia akan berusaha memenuhi kebutuhan tersebut (Yuniarwati, 2018). Tingkat motivasi belajar siswa tidak sama antara satu orang dengan orang lain. Seorang guru pembimbing harus bisa mengupayakan agar siswa termotivasi untuk belajar. Kegiatan belajar sangat memerlukan motivasi, hasil belajar akan menjadi optimal kalau ada motivasi. Motivasi adalah kekuatan-kekuatan atau tenaga yang dapat memberikan dorongan kepada kegiatan belajar anak. Guru pembimbing memiliki peranan sebagai motivator dan fasilitator dalam rangka meningkatkan motivasi belajar siswa dalam proses belajar mengajar dengan memberikan layanan bimbingan konseling khususnya melalui layanan bimbingan kelompok (Hartinah, 2016).

Berdasarkan hasil pengamatan guru pembimbing serta pengaduan dari beberapa guru mata pelajaran diperoleh informasi bahwa siswa yang memiliki motivasi belajar rendah tersebar di kelas X MIPS 2 SMA Negeri 9 Kota Jambi. Dari data tersebut menunjukan siswa yang memiliki motivasi belajar rendah sebanyak 17 (56,25\%) siswa dari 35 siswa, sedang yang lainnya yaitu $13(43,75 \%)$ siswa mempunyai motivasi belajar yang bagus. Permasalahan belajar pada siswa SMA Negeri 9 Kota Jambi sangat kompleks. Dalam proses pembelajaran banyak alasan yang dikemukakan siswa untuk menolak kegiatan belajar. Siswa lebih memilih kegiatan yang dirasa lebih menyenangkan dari pada sekedar belajar di kelas. Beberapa siswa di sekolah tersebut sering menunjukkan penolakan dalam belajar. Salah satu faktor yaitu karena ketertarikan belajar siswa yang masih rendah. Hal ini berakibat pada prestasi belajar yang tidak ada perubahan dan bahkan menurun. Fenomena yang terjadi adalah siswa yang memiliki 


\section{EDUCATOR : Jurnal Inovasi Tenaga Pendidik dan Kependidikan Vol. 1 No. 1 September 2021, e-ISSN : 2807-8659 | p-ISSN : 2807-8829}

motivasi belajar rendah cenderung memiliki nilai dengan ketuntasan belajar yang belum cukup masing-masing di minimal 3 mata pelajaran pada semester sebelumnya. Berdasarkan wawancara yang dilakukan, didapati bahwa siswa malas mengikuti pembelajaran, kurang antusias, dan tidak menyelesaikan tugas tepat waktu. Hal ini karena siswa menganggap remeh pelajaran yang diikuti sehingga menjadikan motivasi belajar siswa menjadi menurun.

Permasalahan yang telah diungkapkan di atas, merupakan tantangan bagi pendidik khususnya guru untuk memberikan layanan bimbingan yang tepat dan sesuai untuk siswa yang tujuannya adalah agar kegiatan belajar dapat diikuti dengan nyaman dan senang bagi siswa. Kegiatan bimbingan tersebut dapat diberikan dengan berbagai macam metode. Metode-metode yang diberikan dalam kegiatan bimbingan untuk siswa sangat berkaitan dengan adanya layanan bimbingan dan konseling, salah satunya adalah konseling kelompok. Usaha yang akan dilakukan dalam rangka meningkatkan motivasi belajar siswa yang rendah adalah dengan mengoptimalkan layanan BK kepada siswa. Ada beberapa cara yang dapat dicoba dalam upaya menyelesaikan masalah tersebut, diantaranya pemberian informasi tentang pentingnya motivasi belajar, konseling individu pada siswa yang memiliki motivasi belajar rendah, dan mengadakan bimbingan kelompok.

Dalam penelitian ini, peneliti menggunakan layanan bimbingan kelompok (topik tugas) dengan menggunakan teknik diskusi kelompok. Penggunaan teknik dalam kegiatan bimbingan kelompok mempunyai banyak fungsi selain dapat lebih memfokuskan kegiatan bimbingan kelompok terhadap tujuan yang ingin dicapai tetapi juga dapat membuat kegiatan bimbingan kelompok agar lebih bergairah dan tidak cepat membuat siswa jenuh mengikutinya (Serikandi, 2020). Bimbingan dan konseling kelompok bermaksud memanfaatkan dinamika kelompok sebagai media dalam upaya membimbing individuindividu yang memerlukan (Endrawati, 2019). Senada dengan uraian di atas dijelaskan pula bahwa layanan bimbingan kelompok dapat membantu siswa dalam meningkatkan motivasi belajar siswa. Program bimbingan kelompok yang dikembangkan adalah membantu siswa dalam meningkatkan motivasi belajar. Oleh karena motivasi belajar sendiri menjadi bagian dalam bidang bimbingan belajar sehingga siswa akan ditangani sesuai dengan permasalahan beserta penanganannya (Purnama, dkk, 2017).

Berdasarkan uraian tersebut di atas, penulis tertarik untuk melakukan penelitian tindakan kelas dengan judul "Upaya Meningkatkan Motivasi Belajar Siswa dengan Metode Bimbingan Kelompok Siswa Kelas X MIPS 2 di SMA Negeri 9 Kota Jambi.

\section{METODE PENELITIAN}

Penelitian ini menggunakan penelitian tindakan kelas melalui empat tahapan, yaitu (1) perencanaan, (2) pelaksanaan, (3) pengamatan dan evaluasi (4) refleksi. Subjek dalam penelitian ini adalah 35 Peserta didik Kelas X MIPS 2 di SMA Negeri 9 Kota Jambi yang dikategorikan memiliki motivasi rendah. Untuk mendapatkan subjek penelitian ini, peneliti mendapatkan rekomendasi dari wali kelas, dan guru-guru mata pelajaran. Kemudian dilakukan observasi kepada 35 siswa tersebut dan wawancara untuk mengetahui keadaan siswa sebelum diberikan perlakuan berupa layanan konseling kelompok.

Instrumen penelitian ini menggunakan lembar tes dan lembar observasi. Dalam penelitian ini, peneliti menggunakan metode skala psikologis dengan alat pengumpulan datanya menggunakan skala motivasi belajar. Hal ini dipilih karena yang akan diukur dalam penelitian ini adalah motivasi belajar yang sifatnya abstrak atau tidak dapat diamati langsung maka skala psikologislah yang dirasa peneliti metode paling tepat untuk mengukur motivasi belajar. Teknik analisis data yang digunakan dalam penelitian ini adalah analisis deskriptif kuantitatif dan kualitatif.

Penelitian ini dikatakan berhasil jika terjadi peningkatan motivasi belajar siswa. Motivasi belajar siswa dikatakan meningkat apabila prosentase mencapai $\geq 85 \%$. Motivasi belajar dikatakan meningkat apabila hasil motivasi belajar minimal berkatagori sedang. Dalam penelitian ini yang menjadi indikator kinerja keberhasilan adalah berpedoman pada prosentase penafsiran kategori 52\% $\leq \% \leq 68 \%$ kategori sedang. (Arikunto, 2010). 


\section{HASIL DAN PEMBAHASAN}

\section{Siklus I}

Berdasarkan hasil diagnosis kondisi awal, maka peneliti bersama kolabolator memberikan tindakan kepada siswa yang tergolong memiliki motivasi belajar rendah dan beberapa siswa yang memiliki motivasi belajar diberikan batuan berupa layanan bimbingan kelompok. Pemberian tindakan diberikan sebanyak dua siklus terhadap partisipan/ responden yang berjumlah 35 siswa yang motivasi belajarnya amat rendah. Teknik pelaksanaan layanan bimbingan kelompok terdiri dari perencanaan (Planning), tindakan (Action), pengamatan (Observation), refleksi (Reflection). Untuk mengetahui pelaksanaan layanan dan hasil dari layanan bimbingan kelompok pada siswa digunakan alat bantu berupa instrumen skala motivasi belajar, wawancara, dan observasi.

Perencanaan (Planning), Peneliti bersama kolaborator merencanakan pemberian tindakan berupa layanan bimbingan kelompok pada siklus 1 dengan tujuan untuk meningkatkan kualitas proses dan hasil layanan kelompok khususnya layanan bimbingan kelompok. Perencanaan ini bertujuan agar proses pelaksanaan tindakan berjalan dengan lancar dan sesuai harapan. Adapun perencanaan yang dilakukan oleh peneliti antara lain sebagai berikut: (1) Merencanakan waktu dan tempat penelitian, Waktu pertemuan dilakukan pada hari Senin pukul $10.30-11.30$ WITA. (2) Menentukan materi layanan yang akan diberikan yaitu materi tentang peningkatan motivasi belajar. (3) Menentukan observer penelitian, Observer pada penelitian ini yaitu guru pembimbing (guru BK) SMA Negeri 9 Kota Jambi. (4) Menyiapkan kelengkapan administrasi pendukung penelitian. Kelengkapan yang disiapkan pada perencanaan siklus I antara lain yaitu satuan layanan, materi layanan, pedoman observasi, dan kisi-kisi pertanyaan yang akan diberikan.

Tindakan (Action), Pada tahapan ini, penelitian tidakan ini dilaksanakan sebanyak tiga kali pertemuan pada setiap siklusnya. Peneliti melaksanakan rencanan tindakan layanan bimbingan kelompok sesuai prosedur dan perencanaan yang dilakukan oleh peneliti dan kolaborator. Pada awal pertemuan, peneliti melaksanakan layanan bimbingan kelompok dengan topik tugas Semangat Belajar. Pada pertemuan pertama pemimpin kelompok menekankan pada tahap permulaan dengan saling memperkenalkan diri dan memberikan penjelasan mengenai kegiatan bimbingan kelompok. Pada tahap awal ini pemimpin kelompok dan anggota kelompok saling memberikan pertanyaan untuk saling mengenal satu sama lain. Dalam tahap kegiatan topik yang dibahas adalah "semangat belajar". Selama kegiatan berlangsung anggota kelompok masih belum bisa mengikuti dengan baik, karena anggota kelompok belum memahami tentang proses layanan bimbingan kelompok dengan jelas. Pada pelaksanaan layanan bimbingan kelompok yang pertama, dinamika kelompok belum tercipta dengan baik. Pemahaman anggota kelompok tentang topic yang dibahas juga dirasa masih kurang. Anggota kelompok merasa sangat tertarik untuk melakukan kegiatan bimbingan kelompok selanjutnya. Dalam tahap pengakhiran pemimpin kelompok menyampaikan hasil kesimpulan dari tahap kegiatan yang telah dilakukan dan meminta anggota kelompok untuk mengisi penilaian segera serta menginformasikan pelaksanaan kegiatan bimbingan kelompok lanjutan yang akan segera dilaksanakan.

Pada pertemuan kedua, peneliti melaksanakan layanan bimbingan kelompok dengan topik tugas kemandirian belajar. Dalam tahap kegiatan pemimpin kelompok memberitahukan pada anggota kelompok topik yang akan dibahas pada pertemuan kali ini adalah kemandirian belajar. Selama kegiatan berlangsung anggota kelompok sudah lebih baik dari sebelumnya dalam mengikuti jalannya bimbingan kelompok. Ada beberapa anggota kelompok yang sudah mulai mau mengemukakan pendapatnya. Pada pelaksanaan layanan bimbingan kelompok yang kedua, dinamika kelompok tercipta lebih baik dari sebelumnya namun dirasa masih kurang. Pemahaman anggota kelompok tentang topik yang dibahas juga dirasa lebih baik dari sebelumnya. Namun masih ada siswa yang malu dalam berpendapat. Anggota kelompok merasa sangat tertarik untuk melakukan kegiatan bimbingan kelompok selanjutnya. Dalam 
tahap pengakhiran pemimpin kelompok menyampaikan hasil kesimpulan dari tahap kegiatanyang telah dilakukan dan meminta anggota kelompok mengisi laiseg serta menginformasikan pelaksanaan kegiatan bimbingan kelompok lanjutan yang akan segera dilaksanakan.

Pada pertemuan ketiga, peneliti melaksanakan layanan bimbingan kelompok dengan topik tugas Kepercayaan Diri Belajar. Pada tahap kegiatan, topik yang dibahas yaitu kepercayaan diri belajar. Tujuan dari pembahasan topik ini, yaitu agar anggota kelompok mengetahui arti penting percaya diri dalam belajar dan memiliki kepercayaan diri dalam belajar dan mengerjakan tugas. Proses pelaksanaan layanan bimbingan kelompok pada pertemuan ketiga, semua anggota sudah aktif dan lebih terbuka dalam berpendapat, dinamika kelompok yang diharapkan sudah muncul cukup baik. Pemahaman anggota kelompok mengenai kepercayaan diri belajar sudah cukup, terlihat dari kesimpulan yang dikemukakan anggota kelompok. Dalam tahap pengakhiran pemimpin kelompok menyampaikan hasil kesimpulan dari tahap kegiatan yang telah dilakukan dan meminta anggota kelompok untuk mengisi penilaian segera (laiseg). Setelah kegiatan bimbingan kelompok diakhiri, peneliti meminta anggota kelompok untuk mengisi skala motivasi belajar, guna mengetahui tingkat motivasi belajar anggota kelompok setelah dilaksanakannya siklus 1 (posttest 1 ).

Observasi Aktivitas Guru, Pada saat kegiatan bimbingan kelompok observer mengamati aktivitas guru. Data aktivitas guru dalam melaksanakan kegiatan bimbingan kelompok diperoleh dengan menggunakan lembar observasi aktivitas guru dalam membimbing kelompok yang dibantu oleh observer.

Tabel 1. Hasil Observasi Aktivitas Guru Siklus I

\begin{tabular}{lllcc}
\hline No & \multicolumn{2}{c}{ Indikator } & Skor \\
\hline $\begin{array}{l}\text { 1. Perecanaan dan persiapan penyelenggaraan kegiatan } \\
\text { bimbingan kelompok }\end{array}$ & 3 \\
\hline 2. & $\begin{array}{l}\text { Sikap dan kemampuan guru dalam proses kegiatan } \\
\text { bimbingan kelompok }\end{array}$ & 2 \\
\hline 3 & Penguasaan materi bimbingan kelompok & & 3 \\
\hline 4. & $\begin{array}{l}\text { Implementasi langkah-langkah kegiatan } \\
\text { kelompok }\end{array}$ & bimbingan & 3 \\
\hline 5. & Kemampuan menutup kegiatan bimbingan kelompok & 2 \\
\hline Total skor & 13 \\
\hline Kriteria & Baik \\
\hline
\end{tabular}

Berdasarkan tabel di atas dapat dilihat total skor aktivitas guru kegiatan bimbingan kelompok pada siklus I sebesar 13, diperoleh dari jumlah skor pada setiap indikator. Berdasarkan kriteria aktivitas guru yang tercantum pada bab III maka aktivitas guru pada siklus I dapat dikategorikan baik, karena terletak pada interval $11 \leq \mathrm{A}<15$.

Untuk observasi kegiatan siswa, Berdasarkan analisis hasil observasi aktivitas siswa dalam kegiatan bimbingan kelompok terhadap indikator yang ditetapkan terdapat tiga indikator yang belum maksimal dilakukan oleh sebagian besar siswa yaitu interaksi siswa dengan guru dan partisipasi siswa dalam kegiatan bimbingan kelompok.

Tabel 2. Hasil Observasi Aktivitas Siswa Siklus I

\begin{tabular}{clc}
\hline No & \multicolumn{1}{c}{ Indikator } & Skor \\
\hline 1. & $\begin{array}{l}\text { Kesiapan siswa menerima pelajaran kegiatan bimbingan } \\
\text { kelompok. }\end{array}$ & 11 \\
\hline 2. & $\begin{array}{l}\text { Antusiasme siswa dalam mengikuti kegiatan kegiatan } \\
\text { bimbingan kelompok }\end{array}$ & 10 \\
\hline 3 & $\begin{array}{l}\text { Interaksi siswa dengan guru dalam kegiatan bimbingan } \\
\text { kelompok }\end{array}$ & 10 \\
\hline
\end{tabular}




\begin{tabular}{ccc}
\hline 4. & $\begin{array}{l}\text { Intraksi siswa dengan siswa dalam kegiatan bimbingan } \\
\text { kelompok }\end{array}$ & 11 \\
\hline 5. & $\begin{array}{l}\text { Partisipasi siswa dalam menyimpulkan hasil kegiatan } \\
\text { bimbingan kelompok }\end{array}$ & 10 \\
\hline Total skor & 52 \\
\hline Kreteria & Aktif \\
\hline
\end{tabular}

Berdasarkan tabel di atas, dapat dilihat total skor aktivitas siswa dalam kegiatan bimbingan kelompok pada siklus I sebesar 52, diperoleh dari jumlah skor pada setiap indikator. Berdasarkan kriteria aktivitas siswa yang tercantum pada bab III maka aktivitas siswa pada siklus I dapat dikategorikan aktif, karena terletak berada pada interval $41 \leq \mathrm{A}<$ 60 .

Hasil Evaluasi kegiatan bimbingan kelompok, Evaluasi kegiatan bimbingan kelompok dilaksanakan untuk mengukur sejauh mana kemampuan atau daya seraf siswa dalam kegiatan bimbingan kelompok pada siklus I dapat digambarkan dalam diagram berikut:

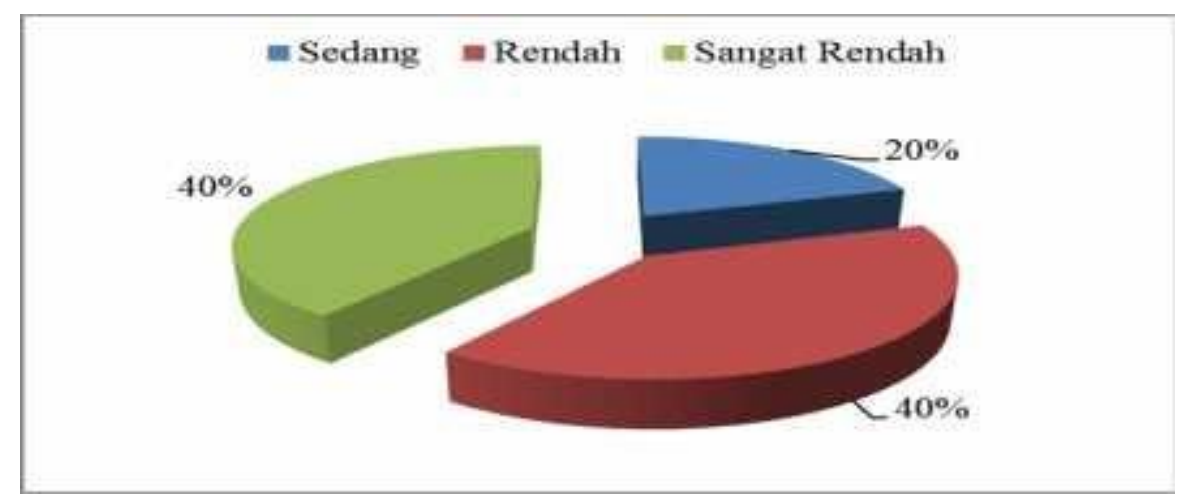

Diagram 1. Hasil instrument kegiatan bimbingan kelompok siklus I

Berdasarkan gambar diagram di atas dimaknai bahwa siswa memiliki motivasi belajar sedang sebanyak $20 \%$, rendah sebesar $40 \%$ dan motivasi belajar kategori sangat rendah $40 \%$.

\section{Siklus II}

Siklus II dalam penelitian ini memberikan tindakan, yaitu layanan bimbingan kelompok dan bertujuan untuk menyempurnakan hasil siklus 1 . Perbedaan siklus 1 dan siklus II terletak pada dinamika kelompok. Jika pada siklus 1 menggunakan permainan secara individu, maka pada siklus II ini menggunakan permainan yang membutuhkan kerjasama dan berkaitan dengan topic bimbingan belajar. Siklus II dalam penelitian ini merupakan perbaikan atau penyempurnaan dari siklus 1 yang belum dijalankan secara maksimal oleh peneliti. Hasil perbaikan pelaksanaan tindakan pada siklus II dilaksanakan dalam 4 tahap yaitu tahap perencanaan, tindakan, pengamatan, dan refleksi. Berikut dipaparkan masing-masing tahapannya.

Perencanaan, Sebelum memulai tindakan pada siklus II, peneliti terlebih dahulu membuat perencanaan kembali agar tindakan yang dilakukan peneliti pada siklus II dapat berjalan dengan baik dan sesuai dengan tujuan penelitian.

Tindakan, Pada tahap tindakan ini, peneliti melaksanakan tindakan layanan bimbingan kelompok sesuai dengan tahapan layanan bimbingan kelompok. Tahap tindakan pada siklus 2 ini dilaksanakan sebanyak tiga kali pertemuan. Masing-masing pertemuan dilakukan satu kali layanan bimbingan kelompok topik tugas.

Pengamatan, Pengamatan dilakukan untuk mengetahui sejauh mana tindakan layanan bimbingan kelompok dapat berjalan dengan baik. Tahap ini dilakukan pengamatan proses dan hasil dari pemberian tindakan layanan bimbingan kelompok.

Observasi, Data aktivitas guru dalam melaksanakan kegiatan bimbingan kelompok diperoleh dengan menggunakan lembar observasi aktivitas guru oleh observer/ kolaborator. 
Adapun hasil observasi aktivitas guru dalam kegiatan bimbingan kelompok siklus II dapat dilihat pada tabel berikut ini.

Tabel 3. Hasil Observasi Aktivitas Guru Siklus II

\begin{tabular}{lllc}
\hline No & \multicolumn{2}{c}{ Indikator } & Skor \\
\hline 1. & $\begin{array}{l}\text { Perecanaan dan persiapan penyelenggaraan } \\
\text { bimbingan kelompok siklus II }\end{array}$ & kegiatan & 3 \\
\hline 2. & $\begin{array}{l}\text { Sikap dan kemampuan guru dalam proses } \\
\text { bimbingan kelompok siklus II }\end{array}$ & kegiatan & 3 \\
\hline 3 & Penguasaan materi bimbingan kelompok siklus II & 3 \\
\hline 4. & $\begin{array}{l}\text { Implementasi langkah-langkah kegiatan bimbingan } \\
\text { kelompok Siklus II }\end{array}$ & 3 \\
\hline 5. & Kemampuan menutup kegiatan bimbingan kelompok & 2 \\
\hline Total skor & Baik \\
\hline Kriteria
\end{tabular}

Berdasarkan tabel di atas dapat dilihat total skor aktivitas guru kegiatan bimbingan kelompok pada siklus II sebesar 14, diperoleh dari jumlah skor pada setiap indikator. Berdasarkan kriteria aktivitas guru yang tercantum pada bab III maka aktivitas guru kegiatan bimbingan kelompok pada siklus II dapat dikategorikan baik, karena terletak pada interval 11 $\leq \mathrm{A}<15$.

Berdasarkan analisis hasil observasi aktivitas siswa dalam kegiatan bimbingan kelompok terhadap indikator sudah dilakukan sesuai harapan guru dalam kegiatan bimbingan kelompok. Adapun hasil observasi dapat dilihat pada tabel berikut.

Tabel 4. Hasil Observasi Aktivitas Siswa Siklus II

\begin{tabular}{clc}
\hline No & \multicolumn{1}{c}{ Indikator } & Skor \\
\hline 1. & $\begin{array}{l}\text { Kesiapan siswa menerima pelajaran kegiatan bimbingan } \\
\text { kelompok. }\end{array}$ & 11 \\
\hline 2. & $\begin{array}{l}\text { Antusiasme siswa dalam mengikuti kegiatan kegiatan } \\
\text { bimbingan kelompok }\end{array}$ & 11 \\
\hline 3 & $\begin{array}{l}\text { Interaksi siswa dengan guru dalam kegiatan bimbingan } \\
\text { kelompok }\end{array}$ & 10 \\
\hline 4. & $\begin{array}{l}\text { Intraksi siswa dengan siswa dalam kegiatan bimbingan } \\
\text { kelompok }\end{array}$ & 11 \\
\hline 5. & $\begin{array}{l}\text { Partisipasi siswa dalam menyimpulkan hasil kegiatan } \\
\text { bimbingan kelompok }\end{array}$ & 53 \\
\hline Total skor & Aktif \\
\hline Kreteria
\end{tabular}

Berdasarkan tabel di atas, dapat dilihat total skor aktivitas siswa dalam kegiatan bimbingan kelompok pada siklus II sebesar 53, diperoleh dari jumlah skor pada setiap indikator. Berdasarkan kriteria aktivitas siswa yang tercantum pada bab III maka aktivitas siswa dalam menerima bimbingan pada siklus II dapat dikategorikan sangat aktif, karena terletak berada pada interval $41 \leq \mathrm{A}<60$.

Hasil Evaluasi kegiatan bimbingan kelompok, Evaluasi kegiatan bimbingan kelompok dilaksanakan untuk mengukur sejauh mana kemampuan atau daya seraf siswa dalam memahami materi kegiatan bimbingan kelompok dalam meningkatkan motivasi belajar pada siklus II dengan rincian dapat digambarkan dalam diagram berikut: 


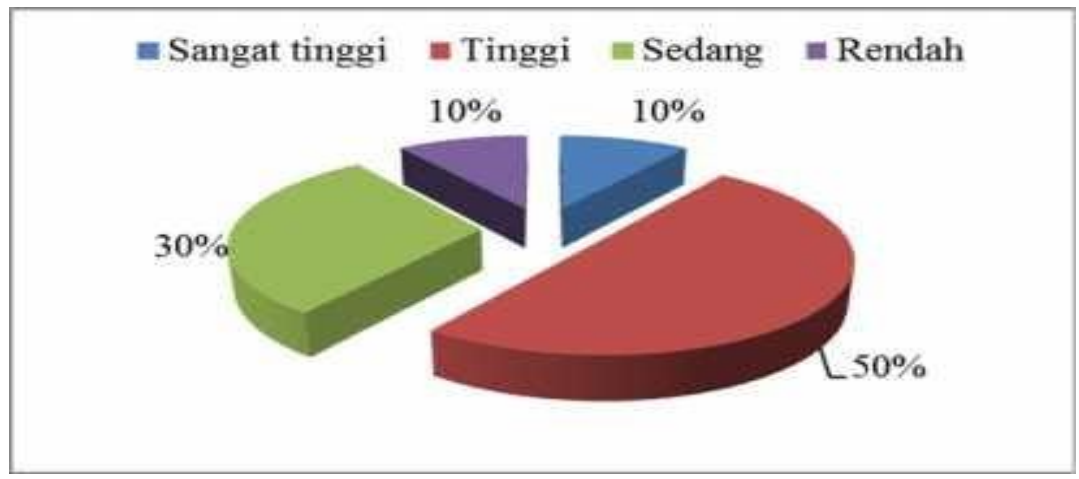

Diagram 2. Hasil instrument kegiatan bimbingan kelompok siklus II

Berdasarkan gambar diagram di atas dimaknai bahwa siswa memiliki motivasi belajar sangat tinggi sebanyak 10\%, tinggi sebesar 50\% dan motivasi belajar kategori sedang sebesar $10 \%$ dan rendah $10 \%$.

\section{KESIMPULAN}

Berdasarkan hasil penelitian yang sudah dipaparkan, maka peneliti dapat menarik kesimpulan yaitu: 1) Penelitian ini dilaksanakan sesuai dengan prosedur Penelitian Tindakan Bimbingan dan Konseling yang telah ditetapkan dari awal dengan perencanaan, pelaksanaan tindakan, observasi, dan evaluasi yang dilanjutkan dengan refleksi. Tahap perencanaan siklus I dan II yang dilakukan adalah menyiapkan rencana pembelajaran, lembar observasi untuk mencatat aktivitas guru dan siswa sebagai salah satu penentu indikator keberhasilan, memahami materi kegiatan bimbingan kelompok dalam meningkatkan motivasi belajar siswa sebagai penilaian sekaligus sebagai bahan evaluasi dan merencanakan hasil analisis. 2) Berdasarkan hasil analisis data pelaksanaan tindakan pada siklus I menunjukkan bahwa prosentase motivasi belajar sedang sebanyak $20 \%$, rendah sebesar $40 \%$ dan motivasi belajar kategori sangat rendah $40 \%$. Sedangkan berdasarkan hasil analisis siklus II diperoleh siswa memiliki motivasi belajar sangat tinggi sebanyak 10\%, tinggi sebesar 50\% dan motivasi belajar kategori sedang sebesar $10 \%$ dan rendah $10 \%$. Dari data tersebut dapat dilihat bahwa apabila motivasi belajar siswa meningkat maka hasil bimbingan kelompok siklus II sehingga telah mencapai indikator keberhasilan yang ditetapkan.

\section{DAFTAR PUSTAKA}

Arikunto, Suharsimi. (2010). Prosedur Penelitian. Jakarta: PT Rineka Cipta.

Damanik, B. E. (2019). Pengaruh Fasilitas Dan Lingkungan Belajar Terhadap Motivasi Belajar. Publikasi Pendidikan, 9(1), 46-52.

Endrawati, S. (2019). Upaya Peningkatan Motivasi Belajar Siswa Melalui Layanan Bimbingan Kelompok. Empati-Jurnal Bimbingan dan Konseling, 6(1), 31-43.

Fitriati, T. K. (2017). Meningkatkan Motivasi Belajar Siswa pada Mata Pelajaran Matematika Melalui Pendekatan Bimbingan Kelompok. Insight: Jurnal Bimbingan Konseling, 6(1), $88-100$

Hanan, H. A. (2017). Meningkatkan Motivasi Belajar Bimbingan konseling Siswa Kelas VIII. C Melalui Bimbingan Kelompok Semester Satu Tahun Pelajaran 2015/2016. Jurnal Ilmiah Mandala Education, 3(1), 62-72.

Hartinah, G. (2016). Upaya Meningkatkan Motivasi Belajar Siswa Melalui Layanan Bimbingan Kelompok Menggunakan Metode Problem Solving. Jurnal Konseling Gusjigang, 2(2).

Is, J. Musnadi. (2017, October). Analisis Pola Asuh Orang Tua Dengan Perkembangan Sosialisasi Remaja Di Sma Negeri 1 Kaway Xvi Kabupaten Aceh Barat. In Prosiding Seminar Nasional USM (Vol. 1, No. 1).

Khairani, K. (2019). Mengatasi Kenakalan Peserta Didik melalui Bimbingan Kelompok di SMK Negeri 1 Bireun. Jurnal Serambi Akademica, 7(4), 391-398. 
Priyatno \& Ermananti. (2005). Dasar-Dasar bimbingan Konseling. Edisi Revisi. Jakarta: Rineka Cipta.

Purnama, A., Yusmansyah, Y., \& Mayasari, S. (2017). Meningkatkan Motivasi Belajar Siswa Melalui Penggunaan Layanan Bimbingan Kelompok Pada Siswa Kelas VII. ALIBKIN (Jurnal Bimbingan Konseling), 5(6).

Ridho, M. A. (2012). Pengaruh lingkungan terhadap motivasi belajar dan dampaknya terhadap prestasi belajar siswa kompetensi keahlian audio video smk muh. kutowinangun kebumen. Skripsi. Yogyakarta: Fakultas Teknik UNY.

Serikandi, B. (2020). Upaya Meningkatan Motivasi Belajar Siswa Melalui Layanan Bimbingan Kelompok di Kelas XII-IIS-1 SMA Negeri 1 Pujut. Jurnal Paedagogy, 7(2), 78-89.

Yuniarwati, C. T. (2018). meningkatkan motivasi belajar melalui layanan bimbingan kelompok dengan teknik modeling pada siswa kelas Xi A $\neg$ Ph 1 SMK NI cepu semester gasal tahun 2017/2018. Empati-Jurnal Bimbingan dan Konseling, 5(1). 